\title{
Exhaled nitric oxide during acute changes of airways calibre in asthma
}

\author{
P. Garnier, I. Fajac, J.F. Dessanges, J. Dall'Ava-Santucci, \\ A. Lockhart, A.T. Dinh-Xuan
}

Exhaled nitric oxide during acute changes of airways calibre in asthma. P. Garnier, I. Fajac, J.F. Dessanges, J. Dall'Ava-Santucci, A. Lockhart, A.T. Dinh-Xuan. (OERS Journals Ltd 1996.

ABSTRACT: It has been shown that endogenous nitric oxide (NO), measured in exhaled air, is increased in asthmatic subjects and after allergen challenge in sensitized animals. NO is also a paracrine molecule with some, though weak, bronchodilator effects. However, whether the amount of endogenous NO that originates in the lungs can reflect the degree of bronchial tone and airways calibre in asthmatic subjects has not yet been investigated. The aim of this study was, therefore, to determine whether NO production could be modified by acute changes of airways calibre in mild, nonatopic, asthmatic subjects.

NO output was measured in the exhaled air of 14 steroid-free asthmatics, 8 steroidtreated asthmatics and 21 control subjects. In seven steroid-free asthmatics, exhaled NO was measured after methacholine challenge, and then after salbutamol-induced bronchial dilatation. Exhaled tidal breathing was collected for $30 \mathrm{~s}$ and NO in the exhaled air was measured with a chemiluminescence analyser.

Both NO concentration and its output were significantly higher in the steroid-free asthmatic patients $\left(15.6 \pm 1.5\right.$ parts per billion (ppb) and $6.3 \pm 0.7 \mathrm{nmol} \cdot \mathrm{min}^{-1}$, respectively) as compared with the control subjects $\left(8.9 \pm 1.0 \mathrm{ppb}\right.$ and $3.5 \pm 0.3 \mathrm{nmol} \cdot \mathrm{min}^{-1}$, respectively; $\mathrm{p}<\mathbf{0 . 0 0 1}$ for both) and with the steroid-treated asthmatic patients $\left(11.3 \pm 3.3 \mathrm{ppb}\right.$ and $3.7 \pm 0.9 \mathrm{nmol} \cdot \mathrm{min}^{-1}$, respectively; $p<0.05$ for both). Neither methacholine-induced bronchial obstruction nor salbutamol-induced bronchial dilatation caused a significant change in exhaled NO.

We conclude that NO production is higher in steroid-free than in steroid-treated asthmatics and in control subjects. Furthermore, NO production is not affected by acute pharmacologically-induced changes of airways calibre in asthmatic subjects. Our results suggest that NO production is a marker of airways inflammation rather than an endogenous modulator of bronchial tone in asthma.

Eur Respir J., 1996, 9, 1134-1138.
Service de Physiologie-Explorations Fonctionnelles, C.H.U. Cochin Port-Royal, Université René Descartes, Paris, France.

Correspondence: A.T. Dinh-Xuan

Service de Physiologie-Explorations Fonctionnelles

Hôpital Cochin

27, rue du faubourg Saint-Jacques

75679 Paris cedex 14

France

Keywords: Asthma

bronchial hyperresponsiveness

bronchial reversibility

methacholine

nitric oxide

salbutamol

Received: July 211995

Accepted after revision February 251996
The free radical gas nitric oxide (NO) is a potent pulmonary vasodilator [1], which is synthesized from the amino acid, L-arginine, and molecular oxygen through the action of constitutive and inducible NO synthase (NOS) isoforms [2]. Inducible NOS (iNOS) is expressed in various resident respiratory and inflammatory cells [3-7]. Its expression is enhanced after exposure to certain cytokines [7], and is inhibited by corticosteroids [8].

There is a growing body of evidence that NO might play a role in asthma $[9,10]$. Exogenous $\mathrm{NO}$, given by inhalation, reverses methacholine-induced bronchoconstriction in animals [11-13] and in humans, including healthy subjects [14] and asthmatic patients [15]. NO is a potent bronchial vasodilator in animal airways [16], and may either increase [17] or tonically suppress [18] airways plasma exudation in animals. Various investigators have found that the amounts of NO measured in the exhaled air $[19,20]$ are higher in asthmatic patients as compared with healthy control subjects [21-23]. Furthermore, expired NO output is increased both after allergen- and prostaglandin $\mathrm{F}_{2 \alpha}\left(\mathrm{PGF}_{2 \alpha}\right)$-induced bronchoconstriction in sensitized guinea-pigs [24].

The mechanism of the increase in NO output has not yet been fully investigated, and changes in bronchial tone might, by themselves, modify NO production and output in such experiments. Our aim was, therefore, to study the effects on expired NO of pharmacological agents with no known proinflammatory effects, namely methacholine and salbutamol, in order to separate the effects of inflammation, on the one hand, and changes in bronchial tone, on the other hand, on NO production in asthma. Thus, we firstly determined the level of NO in the exhaled air of steroid-free asthmatic patients and compared it with that of steroid-treated asthmatic patients and control subjects. Secondly, we measured NO production before and after methacholine- and salbutamol-induced acute changes in airways calibre in asthmatic patients. 


\section{Subjects and methods}

\section{Subjects}

NO output was measured in the exhaled air of 22 asthmatic patients and 21 healthy subjects. The asthmatic patients (10 males and 12 females; (mean \pm SEM) age $41 \pm$ 4 yrs) had a history of atopic asthma graded as mild. All of them were nonsmokers. Fourteen patients received either no regular treatment or inhaled $\beta_{2}$-agonists alone. The remaining eight patients were treated with inhaled steroids (beclomethasone dipropionate or budesonide) on a regular basis. The steroid-treated patients also received inhaled $\beta_{2}$-agonists, but only one of them did so on a regular basis (two puffs of salbutamol, four times a day), whereas the remaining seven took $\beta_{2^{-}}$ agonists only on an as-needed basis. The group average value $( \pm$ SEM) of forced expiratory volume in one second (FEV1) for the steroid-free and the steroid-treated patients was $92 \pm 4$ and $73 \pm 7 \%$ of predicted values, respectively.

The 21 nonatopic controls (11 males and 10 females; (mean \pm sem) age $34 \pm 3$ yrs) were nonsmokers. None of them had a history of respiratory or cardiovascular disease or was receiving long-term medication. Their FEV1 was $95 \pm 2 \%$ pred. The study was approved by the Ethics Committee of our hospital. Each subject signed an informed consent form.

\section{Study design}

Lung function parameters and NO in the exhaled air were measured in all subjects at baseline. In seven of the steroid-free asthmatic subjects whose FEV1 was normal, NO in the exhaled air was also measured 2, 5, 10 and $20 \mathrm{~min}$ after completion of a bronchial challenge, with methacholine having caused a fall in FEV $1 \geq 15 \%$ of baseline. NO in the exhaled air was measured again, $10 \mathrm{~min}$ after inhalation of salbutamol $(400 \mu \mathrm{g})$, when FEV1 had returned to the prechallenge value.

\section{Technical details}

Lung function measurements. FEV1 was measured with an automated electronic spirometer (Autospiro AS 500; Minato, Medical Science Co., Osaka, Japan), whose accuracy was regularly verified with a calibrated $3 \mathrm{~L}$ syringe.

NO measurements. NO was measured on a chemilumiscence analyser (CLD 700 AL; Eco Physics) with a detection threshold of 1 part per billion ( $\mathrm{ppb}$ ). Before each study, the analyser was calibrated using NO-free air and a certified gas cylinder of $700 \mathrm{ppb}$ of NO. The subjects with the nose occluded were asked to breathe at tidal volume for $30 \mathrm{~s}$ through a mouthpiece connected to a Hans Rudoph valve. Inspired air was delivered from a tank containing $21 \% \mathrm{O}_{2}$ balanced in $79 \% \mathrm{~N}_{2}$. Even in the ppb range, no trace of $\mathrm{NO}$ was detectable in the inspired air. Expired air was collected during the $30 \mathrm{~s}$ in a Douglas bag, from which gas was sampled through the NO analyser at a known flow-rate during a period of time whose duration was precisely measured with a stopwatch. The volume of gas remaining in the Douglas bag was measured with a water-sealed spirometer, and was added to the volume of the gas sample.

Methacholine bronchial challenge. Methacholine bronchial challenge was performed according to standard procedures. Briefly, methacholine was administered with a breath-activated dosimeter (Rosenthal-French, model D2A; Laboratory of Applied Immunology, Baltimore, MD, USA) and a nebulizer (No. 646; DeVilbiss Co., Somerset, PA, USA). The aerosol was produced by an oxygen flow at a pressure of $1.38 \mathrm{kPa}$, and was inhaled during tidal breathing with the patient's nose occluded. Each activation of the dosimeter delivered a preset quantity of nebulized solution (output $120 \mu \mathrm{L}$ ) in order to deliver the required amount of methacholine. Volume history was standardized by having each subject inhale from functional residual capacity (FRC) to total lung capacity (TLC). Methacholine was diluted in $\mathrm{NaCl} 0.09 \%$. The first dose of methacholine delivered was $100 \mu \mathrm{g}$. Thereafter, one to four serially doubling doses (2-16 times the initial dose) were administered at intervals of 5 min, until a fall in FEV $1 \geq 15 \%$ from prechallenge FEV 1 was reached.

\section{Statistical analysis}

Comparisons between groups were made by analysis of variance (ANOVA) and Scheffe's test. Simple linear regression was used to correlate the percentage changes in exhaled NO from baseline levels with percentage changes of FEV1 induced by methacholine and salbutamol. Results are expressed as mean \pm SEM. A p-value of less than $5 \%$ was considered significant.

\section{Results}

\section{NO at baseline}

NO concentration and NO output in the exhaled air were significantly higher in the steroid-free asthmatic patients $\left(15.6 \pm 1.5 \mathrm{ppb}\right.$ and $6.3 \pm 0.7 \mathrm{nmol} \cdot \mathrm{min}^{-1}$, respectively), as compared both to the steroid-treated asthmatic patients $\left(11.3 \pm 3.3 \mathrm{ppb}\right.$ and $3.7 \pm 0.9 \mathrm{nmol} \cdot \mathrm{min}^{-1}$, respecti-

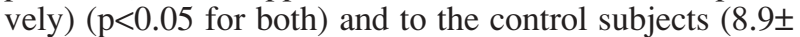
$1.0 \mathrm{ppb}$ and $3.5 \pm 0.3 \mathrm{nmol} \cdot \mathrm{min}^{-1}$, respectively) $(\mathrm{p}<0.001$ for both) (fig. 1). Neither NO concentration nor NO output of steroid-treated patients differed from those of control subjects (fig. 1).

\section{NO measurements after methacholine challenge and salbu-} tamol

After bronchial methacholine challenge, the mean fall of FEV1 was $19 \pm 2 \%$. NO production was lower after methacholine provocation in five patients and higher in the remaining two (fig. 2a). For the group as a whole, no significant change in NO production was observed after methacholine $\left(4.2 \pm 0.7 \mathrm{nmol} \cdot \mathrm{min}^{-1}\right.$ before and $3.3 \pm$ 


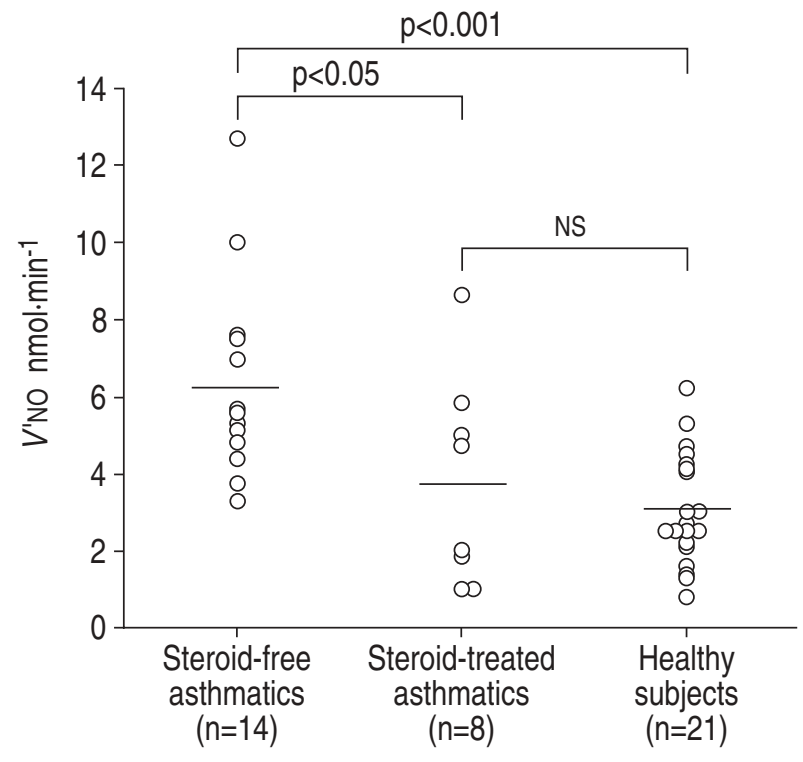

Fig. 1. - Individual values of NO output $\left(V^{\prime} \mathrm{NO}\right)$ in steroid-free, steroid-treated asthmatic patients and healthy nonsmoking subjects. Horizontal bars represent mean values for each group.
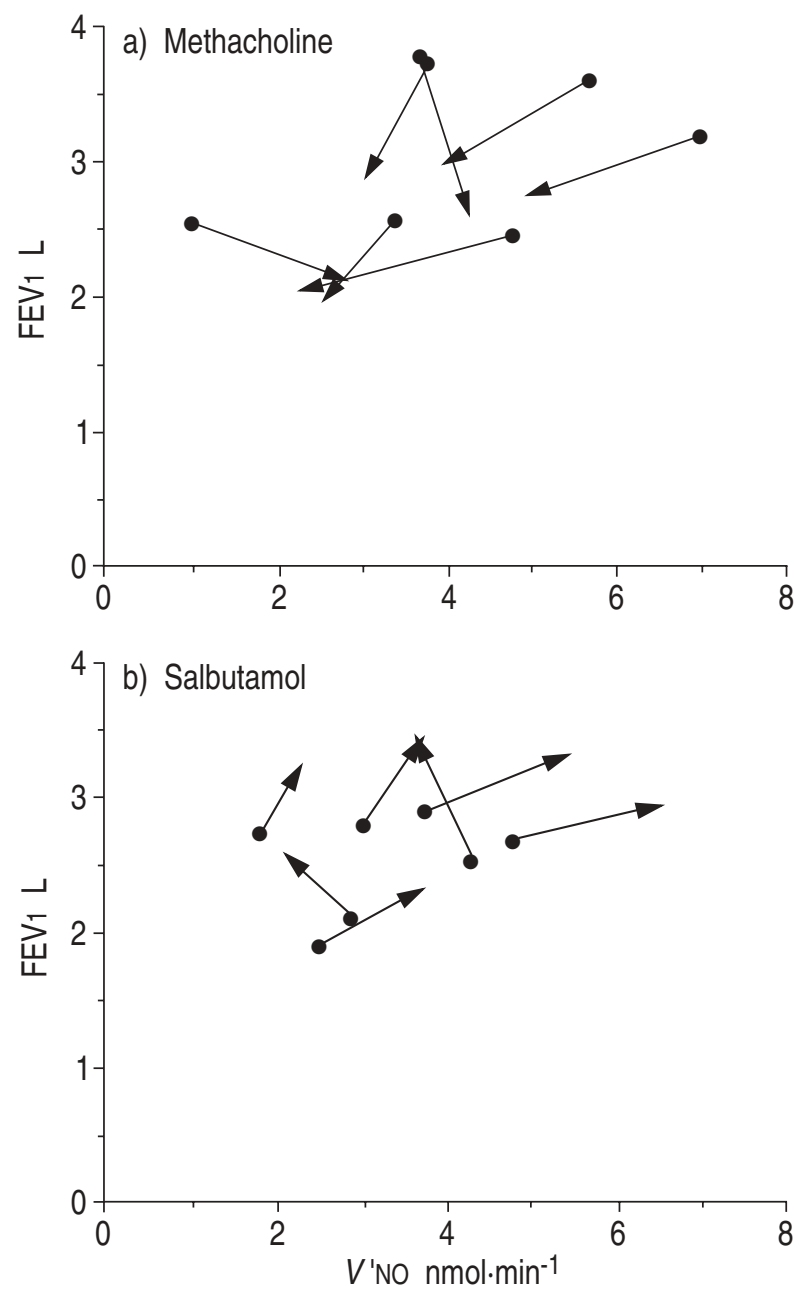

Fig. 2. - Individual changes in NO output $\left(V^{\prime} \mathrm{NO}\right)$ in asthmatic patients a) after bronchial obstruction induced by methacholine. $V^{\prime} \mathrm{NO}$ does not significantly change with methacholine-induced fall in forced expiratory volume in one second (FEV1). b) after bronchial dilatatation induced by salbutamol. $V$ 'NO does not significantly change with salbutamol-induced increase in FEV1.

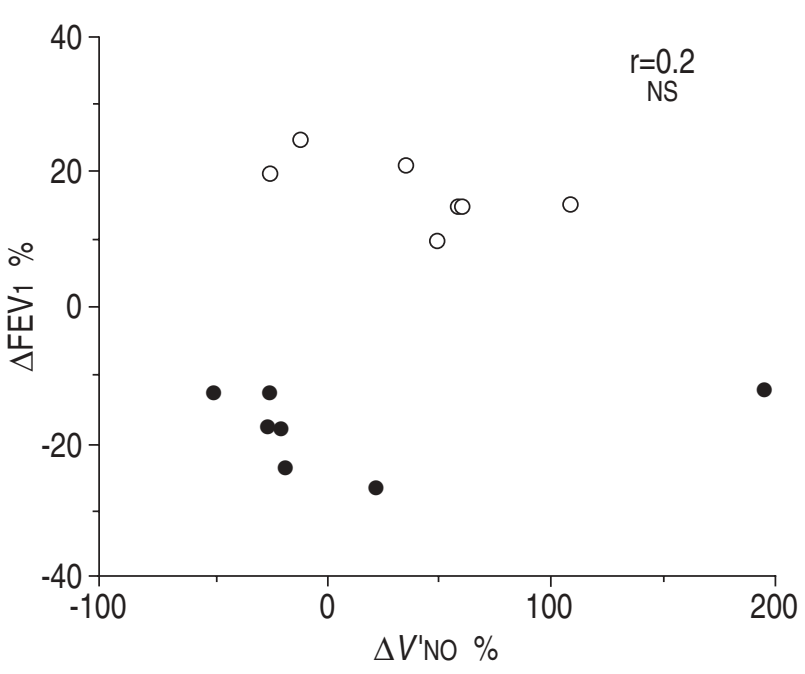

Fig. 3. - Lack of relationship between percentage changes of NO output ( $\left.\Delta V^{\prime} \mathrm{NO}\right)$ and acute changes of airway calibre induced by methacholine (closed symbols) and salbutamol (open symbols). $\triangle F E V 1$ : change in forced expiratory volume in one second.

$0.4 \mathrm{nmol} \cdot \mathrm{min}^{-1}$ after; NS). In addition, there was no correlation between the methacholine-induced fall in FEV1 and the variation of $\mathrm{NO}$ output before and after methacholine challenge ( $\mathrm{r}=0.11$; NS).

Inhalation of salbutamol induced a mean increase in FEV 1 of $16 \pm 2 \%$. NO production increased in 5 out of 7 patients (fig. 2b). However, no significant change in the group-average NO output was observed after salbutamol-induced bronchodilatation $\left(3.3 \pm 0.4 \mathrm{nmol} \cdot \mathrm{min}^{-1}\right.$ before and $4.3 \pm 0.6 \mathrm{nmol} \cdot \mathrm{min}^{-1}$ after; NS). Similarly, there was no correlation between the increase in FEV1 and the variation between pre- or post-salbutamol NO output ( $\mathrm{r}=$ 0.18 ; NS).

No correlation was found either when considering the changes in airway calibre, as shown by an increase or a decrease in FEV1 from baseline FEV1 with respect to the changes in NO output from baseline levels ( $\mathrm{r}=0.2$; NS) (fig. 3).

\section{Discussion}

Our study shows that NO output in the exhaled air is increased in steroid-free asthmatic patients as compared with control subjects, whereas NO output of steroidtreated asthmatic patients does not differ from control subjects. Furthermore, NO output is not affected by acute pharmacologically-induced changes of airway calibre in asthmatic patients.

The increased NO production in the steroid-free asthmatic patients as compared to control subjects is consistent with previous studies [21-23]. It is likely that NO is predominantly synthesized in the upper respiratory tract $[21,25,26]$, which probably accounts for most of the increase of exhaled NO during acute viral infections in healthy subjects [27].

$\mathrm{NO}$ is formed from the amino acid, L-arginine, by the action of an enzyme NOS, which exists as constitutive and inducible forms [2]. In animals, iNOS is expressed in various respiratory cells, such as bronchial epithelial cells [3], alveolar macrophages [4], lung fibroblasts [5], and pulmonary vascular smooth muscle [7]. In humans, 
both constitutive and inducible isoforms of NOS are expressed, and have recently been localized by immunocytochemical and immunohistochemical techniques, in lung tissue $[28,29]$. Transcription of the genes encoding for constitutive neuronal and inducible NOS has also been demonstrated by reverse transcription-polymerase chain reaction in normal human lung epithelial cells in culture [30]. Furthermore, recent evidence suggests that an inducible-like NOS is constitutively expressed in human paranasal sinuses [31], and that NO is continuously synthesized by iNOS in normal human airway epithelium in vivo [32]. However, expression of iNOS seems to depend upon the conditions that are present in the airway of normal individuals, as removal of the epithelial cells from the airway environment leads to rapid loss of iNOS expression [32]. It is likely that the many inflammatory processes which occur within the airway might account for the increased expression of iNOS in bronchial epithelium [33], hence increased NO production in disease such as asthma [21-23], or bronchiectasis [34].

In asthma, many cytokines are upregulated [35, 36], including tumour necrosis factor- $\alpha$, interleukin- $1 \beta$, and interferon- $\gamma$, which are known to induce NOS [37]. It is also known that the latter is inhibited by corticosteroids [8]. Therefore, cytokine-induced upregulation of NOS may well account for the increased output of NO in steroid-free asthmatic subjects. On the other hand, the normal NO output that we found in steroid-treated asthmatics is compatible with the downregulation of iNOS, which is consistent with a previous report [22]. NO is a potent vasodilator both for the pulmonary [1] and bronchial [16] circulations. Furthermore, it increases plasma exudation from airways vessels [17]. Thus, the high level of NO production that we observed in asthmatic patients may reflect the harmful effects that NO might exert, as a proinflammatory mediator, in asthma. However, further studies are needed to relate the level of NO production and the extent of inflammation in asthma.

We found no significant change in NO production after acute pharmacologically-induced variations of airways calibre. Therefore, the immediate and short-lasting increase in NO output that has been described both after antigen-induced bronchoconstriction and administration of the smooth muscle constricting agent $\mathrm{PGF}_{2 \alpha}$ in guineapig [24] cannot be ascribed to the changes in bronchomotor tone themselves. It seems, therefore, unlikely that the amounts of exhaled NO could be used as a marker to either reflect bronchial tone or quantify airways calibre in asthma.

$\mathrm{NO}$ is also a neurotransmitter released from inhibitory nonadrenergic-noncholinergic (iNANC) nerves in human airways [38-42]. Furthermore, endogenous NO released from iNANC nerves inhibits cholinergic neural responses via functional antagonism of acetylcholine at the airways smooth muscle [42]. In vivo, inhaled NO reverses methacholine-induced bronchoconstriction in animals [11-13], and both in healthy [14] and asthmatic [15] subjects. Furthermore, an inhibitory effect of endogenous NO on antigen-induced bronchoconstriction has been reported in the guinea-pig [43]. However, in the present study, we found no correlation between NO production in exhaled air before methacholine provocation and the fall in FEV1 induced by methacholine. This makes it unlikely that endogenous NO may somehow modulate methacholine-induced bronchoconstriction in asthmatic subjects.

In summary, we have shown that NO production is higher in steroid-free asthmatic than in steroid-treated asthmatic patients and in control subjects, and that NO output is not affected by acute pharmacologically-induced changes of airway calibre in asthmatic patients. Our results, therefore, provide circumstantial evidence that the increased NO output observed in asthma is best explained by upregulation of inducible NO synthase in airways of asthmatic subjects. Furthermore, it seems likely that exhaled NO should be regarded as a marker of airways inflammation rather than as an endogenous modulator of bronchial tone in asthma.

\section{References}

1. Dinh-Xuan AT. Endothelial modulation of pulmonary vascular tone. Eur Respir J 1992; 5: 757-762.

2. Moncada S, Higgs EA. The L-arginine-nitric oxide pathway. N Engl J Med 1993; 329: 2002-2012.

3. Robbins RA, Hamel FG, Floreani AA, et al. Bovine bronchial epithelial cells metabolize L-arginine to Lcitrulline: possible role of nitric oxide synthase. Life Sci 1993; 52: 709-716.

4. Jorens PG, van Overveld FJ, Bult H, Vermeire PA, Herman AG. L-arginine-dependent production of nitrogen oxides by pulmonary macrophages. Eur J Pharmacol 1991; 200: 205-209.

5. Jorens PG, van Overveld FJ, Vermeire PA, Bult H, Herman AG. Synergism between interleukin- $1 \beta$ and the nitric oxide synthase inducer, interferon- $\gamma$, in rat lung fibroblasts. Eur J Pharmacol 1992; 224: 7-12.

6. Wright CD, Mulsch A, Busse R, Osswald H. Generation of nitric oxide by human neutrophils. Biochem Biophys Res Commun 1989; 160: 813-819.

7. Nakayama DK, Geller DA, Lowenstein CJ, et al. Cytokines and lipopolysaccharide induce nitric oxide synthase in cultured rat pulmonary artery smooth muscle. Am J Respir Cell Mol Biol 1992; 7: 471-476.

8. Knowles RG, Salter M, Brooks SL, Moncada S. Antiinflammatory glucocorticoids inhibit the induction by endotoxin of nitric oxide synthase in the lung, liver and aorta of the rat. Biochem Biophys Res Commun 1990; 172: 1042-1048.

9. Barnes PJ, Belvisi MG. Nitric oxide and lung disease. Thorax 1993; 48: 1034-1043.

10. Dinh-Xuan AT. Rôles du NO en physiopathologie cardiovasculaire et respiratoire. Arch Int Physiol Biochim Biophys 1994; 102: A3-A9.

11. Dupuy PM, Shore SA, Drazen JM, Frostell CG, Hill WA, Zapol WM. Bronchodilator action of inhaled nitric oxide in guinea-pigs. J Clin Invest 1992; 90: 421-428.

12. Högman M, Frostell CG, Arnberg H, Hedenstierna G. Inhalation of nitric oxide modulates methacholine-induced bronchoconstriction in the rabbit. Eur Respir J 1993; 6: 177-180.

13. Högman M, Wei SZ, Frostell CG, Arnberg H, Hedenstierna G. Effects of inhaled nitric oxide on methacholineinduced bronchoconstriction: a concentration-response study in rabbits. Eur Respir J 1994; 7: 698-702.

14. Sanna A, Kurtansky A, Veriter C, Stanescu D. Bronchodilator effect of inhaled nitric oxide in healthy men. $\mathrm{Am}$ J Respir Crit Care Med 1994; 150: 1702-1704. 
15. Högman M, Frostell CG, Hedenström H, Hedenstierna G. Inhalation of nitric oxide modulates adult human bronchial tone. Am Rev Respir Dis 1993; 148: 1474-1478.

16. Alving K, Fornhem C, Weitzberg E, Lundberg JM. Nitric oxide mediates cigarette smoke-induced vasodilatory responses in the lung. Acta Physiol Scand 1992; 146: 407-408.

17. Kuo HP, Liu SF, Barnes PJ. The effect of endogenous nitric oxide on neurogenic plasma exudation in guineapig airways. Eur J Pharmacol 1992; 221: 385-388.

18. Erjefält JS, Erjefält I, Sundler F, Persson CGA. Mucosal nitric oxide may tonically suppress airways plasma exudation. Am J Respir Crit Care Med 1994; 150: 227-232.

19. Gustafsson LE, Leone AM, Persson MG, Wiklund NP, Moncada S. Endogenous nitric oxide is present in the exhaled air of rabbits, guinea-pigs and humans. Biochem Biophys Res Commun 1991; 181: 852-857.

20. Borland CDR, Cox Y, Higenbottam TW. Measurement of exhaled nitric oxide in man. Thorax 1993; 48: 11601162.

21. Alving K, Weitzberg E, Lundberg JM. Increased amount of nitric oxide in exhaled air of asthmatics. Eur Respir $J$ 1993; 6: 1368-1370.

22. Kharitonov SA, Yates D, Robbins RA, Logan-Sinclair $\mathrm{R}$, Shinebourne EA, Barnes PJ. Increased nitric oxide in exhaled air of asthmatic patients. Lancet 1994; 343: 133-135.

23. Persson MG, Zetterström O, Agrenius V, Ihre E, Gustafsson LE. Single-breath nitric oxide measurements in asthmatic patients and smokers. Lancet 1994: 343: 146-147.

24. Persson MG, Gustafsson LE. Allergen-induced airway obstruction in guinea-pigs is associated with changes in nitric oxide levels in exhaled air. Acta Physiol Scand 1993; 149: 461-466.

25. Gerlach H, Rossaint R, Pappert D, Knorr M, Falke KJ. Autoinhalation of nitric oxide after endogenous synthesis in nasopharynx. Lancet 1994; 343: 518-519.

26. Lundberg JON, Weitzberg E, Nordvall SL, Kuylenstierna $\mathrm{R}$, Lundberg JM, Alving K. Primarily nasal origin of exhaled nitric oxide and absence in Kartagener's syndrome. Eur Respir J 1994; 7: 1501-1504.

27. Kharitonov SA, Yates D, Barnes PJ. Increased nitric oxide in exhaled air of normal human subjects with upper respiratory tract infections. Eur Respir J 1995; 8: 295-297.

28. Kobzik L, Bredt DS, Lowenstein CJ, et al. Nitric oxide synthase in human and rat lung: immunocytochemical and histochemical localization. Am J Respir Cell Mol Biol 1993; 9: 371-377.

29. Tracey WR, Xue C, Klinghofer V, et al. Immunochemical detection of inducible NO synthase in human lung. $A m$ J Physiol 1994; 266: L722-L727.
30. Asano K, Chee CBE, Gaston B, et al. Constitutive and inducible nitric oxide synthase gene expression, regulation, and activity in human lung epithelial cells. Proc Natl Acad Sci USA 1994; 91: 10089-10093.

31. Lundberg JON, Farkas-Szallasi T, Weitzberg E, et al. High nitric oxide production in human paranasal sinuses. Nature Med 1995; 1: 370-373.

32. Guo FH, De Raeve HR, Rice TW, Stuehr DJ, Thunnissen FBJM, Erzurum SC. Continuous nitric oxide synthesis by inducible nitric oxide synthase in normal human airway epithelium in vivo. Proc Natl Acad Sci USA 1995; 92: 7809-7813.

33. Hamid Q, Springall DR, Riveros-Moreno V, et al. Induction of nitric oxide synthase in asthma. Lancet 1993; 342: 1510-1513.

34. Kharitonov SA, Wells AU, O'Connor BJ, et al. Elevated levels of exhaled nitric oxide in bronchiectasis. Am J Respir Crit Care Med 1995; 151: 1889-1893.

35. Broide DH, Lotz M, Cuomo AJ, Coburn DA, Federman EC, Wasserman SI. Cytokines in symptomatic asthma airways. J Allergy Clin Immunol 1992; 89: 958-967.

36. Ying S, Robinson DS, Varney V, et al. TNF- $\alpha$ mRNA expression in allergic inflammation. Clin Exp Allergy 1991; 21: 745-750.

37. Warner RL, Paine R III, Christensen PJ, et al. Lung sources and cytokine requirements for in vivo expression of inducible nitric oxide synthase. Am J Respir Cell Mol Biol 1995; 12: 649-661.

38. Belvisi MG, Stretton CD, Yacoub M, Barnes PJ. Nitric oxide is the endogenous neurotransmitter of bronchodilator nerves in humans. Eur J Pharmacol 1992; 210: 221-222.

39. Belvisi MG, Stretton CD, Miura M, et al. Inhibitory NANC nerves in human tracheal smooth muscle: a quest for the neurotransmitter. J Appl Physiol 1992; 73: 2505-2510.

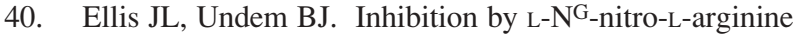
of nonadrenergic-noncholinergic-mediated relaxation of human isolated central and peripheral airways. Am Rev Respir Dis 1992; 146: 1543-1547.

41. Bai TR, Bramley AM. Effect of an inhibitor of nitric oxide synthase on neural relaxation of human bronchi. Am J Physiol 1993; 264: L425-L430.

42. Ward JK, Belvisi MG, Fox AJ, et al. Modulation of cholinergic neural bronchoconstricton by endogenous nitric oxide and vasoactive intestinal peptide in human airways in vitro. J Clin Invest 1993; 92: 736-742.

43. Persson MG, Friberg SG, Hedqvist P, Gustafsson LE. Endogenous nitric oxide counteracts antigen-induced bronchoconstriction. Eur J Pharmacol 1993; 249: R7$\mathrm{R} 8$. 